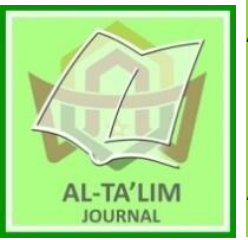

\title{
Factors Affecting Internship Students' Speaking Anxiety
}

\author{
Received: $05^{\text {th }}$ April2019; Revised: $06^{\text {th }}$ April2019; Accepted: $31^{\text {th }}$ July 2019
}

Permalink/DOI: http://dx.doi.org/10.15548/ jt.v26i2.531

\section{Asnawi Muslem}

Universitas Syiah Kuala Banda Aceh, Indonesia

E-mail: drasnawi@unsyiah.ac.id

\section{Ika Apriani Fata*) \\ Universitas Syiah Kuala Banda Aceh, Indonesia \\ E-mail: ika.apriani@unsyiah.ac.id}

\section{Inayatullah}

Universitas Syiah Kuala Banda Aceh, Indonesia

E-mail: inayatullah@gmail.com

*) Corresponding Author

\begin{abstract}
This study is sought to discover the English speaking anxiety factors in class of internship students and to investigate the students' efforts to cope the problems. This research applied qualitative method in addition research subjects were 30 English internship students of Universitas Syiah Kuala in 2015. The data were collected through questionnaire and interview. Both of the instruments were adapted from (Tum \& Kunt, 2013). The study discovered that the major factors of students' speaking anxiety divided into two interrelated groups; psychological and educational factors. Regarding to the psychological factors, the students were anxious and feeling fear of having misunderstanding teachers' instruction and supervision. The educational factors were reflecting to the current bad performance of speaking skill aspects namely; inaccurate of fluency, inappropriate of vocabulary, inappropriate application of grammar rule, insufficient materials preparation and poor of pronunciation. Nevertheless, 16 internship students who were indicated high level of speaking anxiety used various efforts to solve the speaking anxiety such as; practicing, listening to native speaker's utterance, reading English texts, memorizing words, keeping using English in class, learning grammar rule, making note, preparing the material and using audio dictionary. This study concludes that everyone has anxiety and it is common, yet this problem could be reduced by doing some efforts
\end{abstract}

Keywords: Speaking anxiety factors; Speaking English, Efforts; Internship students.

How to Cite: Muslem, A., Fata, I., \& Inayatullah, I. (2019). “So, are you nervous?" Psychological and educational factors affecting internship students' speaking anxiety. Al-Ta Lim Journal, 26(2). doi:http://dx.doi.org/10.15548/jt.v26i2.531

\section{INTRODUCTION}

Studying in Teacher Training and Education Faculty, the students are equipped by some main competences to be learnt during their studies at study program in which pedagogic, personality, professional and social competences (Depdiknas, 2005). After accomplishing several required subjects of four competences such as teaching method, lesson plan, etc., student must take micro teaching for a semester as the teaching practical lesson for implementing the learnt theory in the study program.

Subsequent to accomplishing the required subjects, the internship students take the internship program at the junior or senior high school (PPL FKIP Unsyiah, n.d.). The different situation can affect the students' perception toward the new activity and responsibility to do during the four months forward. The internship students have to teach in the classroom and they are monitored by the English school's supervisor. In this 
adjustment process of internship, the students tend to experience anxiety since it is a psychological aspect of learning and it is common (Riasati, 2011). As said by (Connolly, Simpson, \& Petty, 2006) anxiety is stress feeling about particular situation. However, even if the internship students face the anxious feeling in speaking, they have particular efforts to solve the anxiety problems while speaking at classroom.

A number of studies undertaken on speaking anxiety have been conducted, such as (Tum \& Kunt, 2013) also did a study to internship students in Northern Cyprus Turkey about foreign language speaking anxiety. The result revealed that the speaking anxiety effects in two areas; the application of grammar rule and the implementation of speaking skills itself. Besides, (Kim \& Kim, 2004) also conducted a study to EFL teachers in Korea, the research illustrated that the sources of foreign language teaching anxiety are the limited English proficiency, lack of confidence, lack of knowledge about linguistics and education, insufficient class preparation, having compared to native teachers, fear of negative evaluation and lack of teaching experience. However, there is yet found a research conducted on EFL context in Indonesia to internship students of speaking anxiety factors and the efforts in solving the problem. Thus, this study would fill in this gap. Therefore, it is very essential to discover the factors of speaking anxiety in the classroom and the efforts for preparation prior to teaching at school which were the goals of this research (Ansari, 2015; Huang, 2012; Woodrow, 2006).

\section{Anxiety}

The feel of worry or fear about something is usual among children until adults. This feeling called anxiety. Anxiety is stress feeling about particular situation yet it is normal (Connolly et al., 2006). It is common when someone is going to speak in front of many people, they tend to experience anxiety. Thus, (Smith, 2009) states that anxiety related to the behavioral and emotional disorders. Fata (2015) asserted that every people has different level and different area of anxiety, the anxiety comes and depends on the outside stimulus in a particular circumstance. These differences tend to vary from person to person (Cowden, 2010). Apart from that, the anxious feeling occurrence can be seen from several symptoms such as thinking she/he cannot speak well in the target language, getting butterflies in his/her stomach, his/her heart beating quickly, speaking fast, sweating a lot and becoming wooden-face (Kim \& Kim, 2004).

\section{Speaking Anxiety Factors}

Speaking anxiety provoking came from some different areas, (Merç, 2011) has evidences that the sources of foreign internship students anxiety are the students and class profiles, classroom management, teaching procedures, being observed, the mentors and miscellaneous. Hence, by following (Timina, 2015) findings in Taiwan, it discovered the major causes of student English speaking anxiety belong to three intersect groups: psychological, educational and socio-cultural. With regard to the main psychological cause, the students feel reluctant to speak English aloud for fear of not understanding or misunderstanding the teacher's question or task. The second group of speaking anxiety causes is related to lack of fluency, making errors, poor knowledge of vocabulary and insufficient oral practice in class. Hence, lack of confidence leads to fear of public failure and/or ridicule. Regarding to the socio-cultural cause, it turned out to be the traditional shyness of the Chinese people and their dislike of speaking in public (Blöte, Kint, Miers, \& Westenberg, 2009; Cheng, 2002; Tanveer, 2007).

Moreover, Tseng (2012) figured out the anxiety factors are associated with learner's classroom environment, self perceptions, social environment, limited exposure to the target language, culture difference, social status, gender, strict and formal classroom environment, presentation in the classroom, fear of making mistakes and apprehension about others' evaluation. 
(Ohata, 2005) also reports regarding to his finding in Japan about the basis of learners anxiety are fear of losing face in front of others, lack of self-confidence in their English proficiency and subject matter, competitiveness, test anxiety, culturally fixed beliefs about learning and learning procedures.

\section{Efforts to Solve Speaking Anxiety}

In solving the speaking anxiety appearance, (Tum \& Kunt, 2013) have two ways to increase internship student's confidence are by advising them that it is ordinary to experience the anxiety and increasing their optimism to speak with their peers, native speaker and their future students in classroom by using the target language. Afterwards, (Kim \& Kim, 2004) suggest some ways to do to diminish anxiety such as preparing the material thoroughly, using song or other fun activities, trying to improve your English proficiency, asking native speaker for help, breathing deeply, participating in recreation activities, and using English CDROMs.

Timina (2015) states some suggestions to instructor to diminish the appearance of speaking anxiety among students, such as: as the instructor to speak clear and use the simple language; ask student to practice more; create warm and relaxing classroom atmosphere and gain positive attitude in learning English

\section{METHOD}

This research used qualitative method and took the data from 30 internship students of English Education Study Program, Teacher Training and Education Faculty, Universitas Syiah Kuala Banda Aceh. The subjects were chosen by using purposive sampling due to the researcher wanted to focus on the 30 students who conducted internship program in academic year 2014/2015. The researcher did a preliminary study by giving 15 questionnaire items to English internship students of Syiah Kuala University who have taken internship program. The result showed that $60 \%$ out of 15 students, eight of them were indicated experiencing speaking anxiety while teaching at school.

The instruments are adopted from (Tum \& Kunt, 2013): 1) questionnaire following the Likert's (1932) scale, 2) The interview. The questionnaires were analyzed by using Microsoft Excel to discover the factors of speaking anxiety and the category of internship students' speaking anxiety level. The writer calculated the scores until getting the mean score. The mean scores of each statement were calculated until getting the average. The average value is 3.06. The average values $\leq 3.06$ were categorized low and $\geq 3.06$ categorized high (Miles \& Huberman, 1994). Moreover, the researcher classified the internship students with high level of speaking anxiety $(\geq 3.06)$ and low level of speaking anxiety $(\leq 3.06)$. Apart from that, the researcher also classified each statement of the questionnaire into high and low category. The high category statements were classified as the factors of speaking anxiety in the classroom. The results of the interview were analyzed by using analytic method proposed by (Miles \& Huberman, 1994).

\section{RESULTS AND DISCUSSION}

\section{Internship Students' Categories of High and Low Levels of Speaking Anxiety}

Analysis of the data in term of internship students' categories of high and low level speaking anxiety, it found that 14 of them $(47 \%)$ were indicated as low level of speaking anxiety and 16 of them (53\%) were indicated as high level of speaking anxiety in classroom (Anandari, 2015; Ehrenreich-May \& Bilek, 2012; Freud, 2013; Gkonou, 2011; Saputra, 2018). Thus, there was no significant different between low and high levels of speaking anxiety in term of internship students' quantity. It is shown in the following figure: 


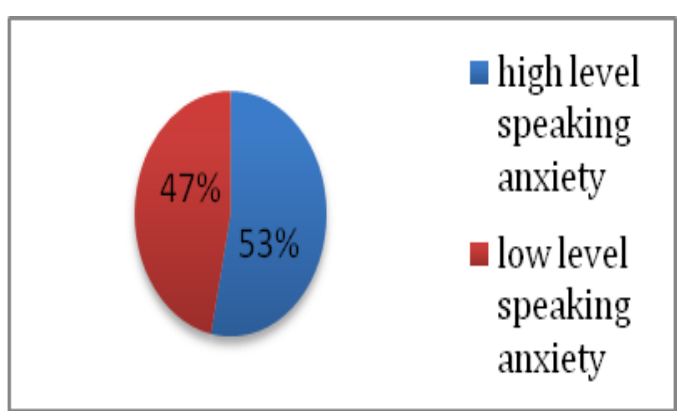

Figure 1. Categories of High and Low Levels of Speaking Anxiety, adopted from(Tum \& Kunt, 2013)

\section{The Factors of Internship Students' Speaking Anxiety}

There are 15 statements that related to the speaking anxiety, there were seven statements mostly chosen which classified as the speaking anxiety provoking and another eight statements were less chosen in this finding.

Table 1. The Questionnaire's Result

\begin{tabular}{|c|c|c|c|c|c|c|c|c|}
\hline No & Statements & $\begin{array}{c}\text { SA* } \\
5\end{array}$ & $\begin{array}{c}\text { A } \\
4\end{array}$ & $\begin{array}{l}\mathbf{N} \\
\mathbf{3} \\
\end{array}$ & $\begin{array}{l}\mathbf{D} \\
\mathbf{2}\end{array}$ & $\begin{array}{c}\text { SD } \\
1\end{array}$ & Mean & Category \\
\hline 1. & $\begin{array}{l}\text { It frightens me when I don't understand what } \\
\text { English school's supervisor (guru pamong) } \\
\text { or student says in English. }\end{array}$ & 2 & 12 & 9 & 5 & 2 & 3.23 & High \\
\hline 2. & $\begin{array}{l}\text { When I am on my way to class, I don't feel } \\
\text { very sure and relaxed. }\end{array}$ & 2 & 3 & 11 & 8 & 6 & 2.57 & Low \\
\hline 3. & $\begin{array}{l}\text { I am afraid that English school's supervisor } \\
\text { (guru pamong) will notice every mistake I } \\
\text { make. }\end{array}$ & 5 & 13 & 8 & 2 & 2 & 3.57 & High \\
\hline 4. & $\begin{array}{l}\text { I feel self-conscious speaking English in } \\
\text { front of the other internship students. }\end{array}$ & 2 & 9 & 7 & 10 & 2 & 2.97 & Low \\
\hline 5. & $\begin{array}{l}\text { When speaking English, I can get so nervous } \\
\text { I forget things I know. }\end{array}$ & 2 & 3 & 11 & 13 & 1 & 2,73 & Low \\
\hline 6. & $\begin{array}{l}\text { I feel overwhelmed by the number of rules } \\
\text { that have to learn in order to speak English. }\end{array}$ & 3 & 8 & 9 & 8 & 2 & 3.07 & High \\
\hline 7. & $\begin{array}{l}\text { I am afraid that the students will laugh at me } \\
\text { when I speak English. }\end{array}$ & & 5 & 11 & 11 & 3 & 2.60 & Low \\
\hline 8. & $\begin{array}{l}\text { I never feel quite sure of myself when I am } \\
\text { speaking English in front of native speakers. }\end{array}$ & 1 & 14 & 7 & 6 & 2 & 3.20 & High \\
\hline 9. & $\begin{array}{l}\text { I am worry about making mistakes in } \\
\text { English. }\end{array}$ & 1 & 17 & 8 & 3 & 1 & 3.47 & High \\
\hline 10. & $\begin{array}{l}\text { I get nervous when I don't understand every } \\
\text { word English school's supervisor (guru } \\
\text { pamong) says. }\end{array}$ & 1 & 14 & 12 & 2 & 1 & 3.40 & High \\
\hline 11. & I don't feel confident when I speak English. & 1 & 4 & 12 & 10 & 3 & 2.67 & Low \\
\hline 12. & $\begin{array}{l}\text { I always feel that other internship students } \\
\text { speak the language better than I do. }\end{array}$ & & 6 & 19 & 3 & 2 & 2.97 & Low \\
\hline 13. & $\begin{array}{l}\text { Even if I am well prepared for class, I feel } \\
\text { anxious about it. }\end{array}$ & & 11 & 9 & 4 & 6 & 2.83 & Low \\
\hline 14. & $\begin{array}{l}\text { When I am going to speak, I am trembling, } \\
\text { sweating, and my heart is beating fast. }\end{array}$ & 2 & 6 & 8 & 8 & 6 & 2.67 & Low \\
\hline 15. & $\begin{array}{l}\text { When I get nervous, sometimes I speak in } \\
\text { Indonesian. }\end{array}$ & 5 & 19 & 5 & & 1 & 3.90 & High \\
\hline & Average & & & & & & 3.06 & \\
\hline
\end{tabular}

$* \overline{\mathrm{SA}}$, Strongly Agree; A, Agree; N, Neutral; D, Disagree; and SD, strongly Disagree.

The following part is the recapitulation of the chosen statements from the highest mean score as the factors of speaking anxiety, as shown in the Table 2 below: 
Table 2. The Chosen Statements of the Questionnaire as the Speaking Anxiety Factors

\begin{tabular}{|c|c|c|c|c|}
\hline No. & The Chosen Statements & $\begin{array}{c}\text { Related Speaking } \\
\text { Aspect }\end{array}$ & The Factors & $\mathbf{Q}$ \\
\hline 1. & $\begin{array}{l}\text { When I get nervous, sometimes I speak in } \\
\text { Indonesian. }\end{array}$ & Vocabulary & Educational & Q15 \\
\hline 2. & $\begin{array}{l}\text { I am afraid that English school's supervisor } \\
\text { notices every mistake I make. }\end{array}$ & Comprehension & Educational & Q3 \\
\hline 3. & I am worry about making mistakes in English. & $\begin{array}{l}\text { Fluency, vocabulary, } \\
\text { grammar, comprehension } \\
\text { and pronunciation. }\end{array}$ & Educational & Q9 \\
\hline 4. & $\begin{array}{l}\text { I get nervous when I don't understand every } \\
\text { word English school's supervisor (guru } \\
\text { pamong) says. }\end{array}$ & $\begin{array}{l}\text { Vocabulary and } \\
\text { comprehension. }\end{array}$ & Psychological & Q10 \\
\hline 5. & $\begin{array}{l}\text { It frightens me when I don't understand what } \\
\text { English school's supervisor (guru pamong) or } \\
\text { student says in English. }\end{array}$ & Vocabulary & Psychological & Q1 \\
\hline 6. & $\begin{array}{l}\text { I never feel quite sure of myself when I am } \\
\text { speaking English in front of native speaker. }\end{array}$ & Pronunciation & Educational & Q8 \\
\hline 7. & $\begin{array}{l}\text { I feel overwhelmed by the number of rules that } \\
\text { have to learn in order to speak English. }\end{array}$ & Grammar & Educational & Q6 \\
\hline
\end{tabular}

The statements in which mostly marked by the internship students were seven items. First, they used Indonesian when they were anxious in speaking (Q15) which referred to vocabulary problem as the educational factor. Second, when English school's supervisor noticed the mistakes internship students made (Q3) which referred to comprehension problem as the educational factor. Next, the internship students were concerned on making mistakes in English (Q9) which referred to fluency, vocabulary, grammar, comprehension, and pronunciation problem as the educational factor (Akkakoson, 2016; Handayani \& Rahmawati, 2017).

Afterwards, the internship students got nervous while they did not understand each word that English school's supervisor (guru pamong) had uttered (Q10) which referred to vocabulary and comprehension problem as the psychological factor. Then, when the internship students did not understand what the English school's supervisor (guru pamong) or student is saying in English (Q1) which also referred to vocabulary problem as the psychological factor. Besides, the internship students felt not sure when they spoke in front of native speaker (Q8) which referred to pronunciation problem as the educational factor. Lastly, the informants felt overwhelmed about rules of English grammar (Q6) which referred to grammar problem as the educational factor.

Reflecting to the chosen questionnaire items above, those were related to the five aspects of speaking skill; fluency, vocabulary, grammar, comprehension and pronunciation. Besides of that, the researcher generalized the factors of speaking anxiety into psychological and educational.

\section{The Interview Result of Internship Students' Efforts}

There were only 16 internship students (high level speaking anxiety) who were invited to the interview session to discover their efforts in solving speaking anxiety problem before teaching. The researcher generalized nine efforts the internship students did prior to teaching in solving their problems in fluency, vocabulary, grammar, comprehension, pronunciation as well as the use of code switch at class.

In solving fluency problem, the internship students preferred to do selfpracticing, peer-practicing and listening to native speakers' utterances through movies or songs. Furthermore, experiencing of poor mastery of vocabulary also could lead the informants' speaking anxiety. Nevertheless, 
they themselves had several efforts to cope with this matter. Some of the informants had a tendency to do some fun activities to enrich their vocabulary such as reading interesting writings;

article, novel, newspaper, etc., then, listening to English songs or watching movies. Besides of such efforts, the internship students preferred to memorize some new words which related to the teaching material taught. Apart from that, most of the informants used code switching while feeling speaking anxiety and experiencing nothing to say. However, the internship solved this problem by keep trying to use English in the classroom.

Afterwards, the ways the internship students did in reducing the incorrect grammar used while speaking were by doing self-learning the grammar even peer-learning prior to teaching. Thus, the researcher gained the comprehension efforts into taking note, preparing the material and practicing to teach. The internship students chose to take a note of the essential points which could be as the reminder to reinforce their comprehension. Besides of that, practicing to teach prior to teaching was also as the preference for the other internship students. Thus, using audio dictionary, listening to native speakers' utterances and self-practicing were chosen as the pronunciation efforts in coping with the pronunciation matter.

\section{The Discussion of Speaking Anxiety Factors}

With regard to the first research question, the internship students marked seven statements as the factors of speaking anxiety. The factors were classified into two interrelated groups; psychological and educational. In accordance with the psychological factors, the students were anxious and fear of not understanding or misunderstanding the teacher's questions or tasks (Timina, 2015). It was shown from the chosen questionnaire statements of $\mathrm{Q} 1$ and Q10 (Table 2).
Afterwards, the educational factors were having bad performance on speaking skill aspects such as inaccurate of fluency, inappropriate of vocabulary, the application of grammar rule, insufficient material preparation and poor of pronouncing words. Those were shown from the chosen questionnaire statements of Q3, Q6, Q8, Q9 and Q15 (Table 2).

In regarding to the educational factor, fluency is connected to another aspect of speaking skill. Thus, this finding could support the theory of (Timina, 2015) agrees that lack of fluency was as the speaking anxiety factor. Moreover, vocabulary problem also could interrupt the process of speaking. This finding had similar evidence with (Tum \& Kunt, 2013) statement that speaking anxiety among student teacher affected in the implementation of speaking skill. Besides of that, (Timina, 2015) also supports that poor knowledge of vocabulary is as the educational factor of speaking anxiety.

Furthermore, lack mastery of grammar is also the source of speaking anxiety. Without using appropriate grammar rule, the produced sentences may become misunderstanding between speakers. As (Tum $\&$ Kunt, 2013) believe that the application of grammar rule is as one of the speaking anxiety provoking. Another source of speaking anxiety is comprehension. Thus, speaking anxiety provoking about having insufficient learning material preparation has been already pointed out by (Kim \& Kim, 2004). Apart from that, (Kim \& Kim, 2004) also state that another source of the speaking anxiety reflected to the feeling fear of negative evaluation. During the internship program, the English school's supervisor evaluated the way the informants deliver the material as well. However, the teacher was not only focus on the material given but also the teaching steps, teaching method used as well as the questions of the students' assessment. As (Tum \& Kunt, 2013) claim that the internship student must also acquire the skills of teaching and they have to 
struggle to understand the fundamentals of teaching methodologies and do best practices.

The internship students also tended to feel of having bad pronunciation they made which can lead to confusing word even sentence. Another problem of having bad pronunciation since there are several words which have quite similar pronunciation yet having dissimilar meaning. Related to this result, (Tum \& Kunt, 2013) believe the speaking anxiety provoking comes in the execution of the speaking skill itself.

\section{The Discussion of Efforts to Solve Speaking Anxiety}

The researcher discovered nine efforts did by the internship programs in diminishing their anxieties in speaking; practicing, listening to native speaker's utterance, reading English texts, memorizing words, keeping using English in class, learning grammar rule, making note, preparing the material and using audio dictionary.

The internship student preferred to do self-practice and peer-practice to reduce the anxiety in speaking. As (Kim \& Kim, 2004) believe to keep trying to improve our English proficiency in speaking. In dealing with this finding, (Tum \& Kunt, 2013) also suggest to encourage optimism by speaking with peers speaking practices. Apart from the effort, the other informants preferred to do such interesting activities such as listening to native speaker's utterance; through movies or songs and reading English texts; article, novel, etc. In relation to this finding, the great of successful language learning is listening to English for an hour or more (Noonan, 2007).

Memorizing some new vocabulary was also chosen in resolving this matter. Furthermore, in reducing the use of code switching in classroom, the informants tried to keep using English while teaching. Related to these findings, (Nguyen \& Tran, 2015) agreed that making English as the habit, it is important to reduce the use of mother tongue. Moreover, relearning the grammar with peer or teacher was also preferred by the informants. As (Riasati, 2011) argues to practice as always with peers and have great motivation to keep learning from teacher.

Thus, the internship students like taking note, preparing the material and practicing to teach. Having well-prepared material and practicing to teach could help the internship students in solving speaking anxiety. They tended to feel confident in transferring the whole material in front of class. In accordance to the findings, anxiety can be solving by preparing the material well (Kim \& Kim, 2004). Furthermore, using audio dictionary was also as a help for it can be used whenever they need the correct pronunciations. Moreover, the internet also be used as the rich sources of free input for pronunciation to gain strategies to understand what you hear (Noonan, 2007).

\section{CONCLUSION RECOMMENDATION}

AND

The factors of internship students' speaking anxiety belong to two interrelated groups; psychological and educational. Regarding to the psychological factors, the students were anxious and fear of having lack comprehension of the English teacher's instruction and supervision. Thus, the educational factors were reflecting to the current bad performance of speaking skill aspects; inaccurate of fluency, inappropriate of vocabulary, the application of grammar rule, insufficient material preparation and poor of pronouncing words.

However, 16 internship students who were indicated high level of speaking anxiety had some efforts to solve the matter such as; practicing, listening native speaker's utterance, reading English writings, memorizing words, keeping using English in class, relearning the grammar, making note, preparing the material and using audio dictionary.

The findings turn out that the internship students tend to code switch their mother tongue (Indonesian/ Acehnese) to solve the anxiety problems. Whilst, this 
finding has not been discussed by the frameworks promoted.

Regarding to the speaking anxiety faced by the internship students, the researcher suggested to the internship students to recognize the speaking anxiety provoking before teaching and do some efforts which could reduce the appearance of speaking anxiety. Furthermore, as the instructor (guru pamong) should know the ability of the internship students and encourage them to gain their confidences since anxiety is common among people. In addition, this research is expected can be a reference for other writers to conduct the study about speaking anxiety among internship students.

\section{REFERENCES}

Akkakoson, S. (2016). Reflections from teachers and students on speaking anxiety in an EFL classroom. Journal of Language and Cultural Education, 4(3), 46-70.

Anandari, C. L. (2015). Indonesian efl students'anxiety in speech production: possible causes and remedy. TEFLIN Journal, 26(1), 1-16.

Ansari, M. S. (2015). Speaking anxiety in ESL/EFL Classrooms: A holistic approach and practical study. International Journal of Education Investigation, 2(4), 38-46.

Blöte, A. W., Kint, M. J., Miers, A. C., \& Westenberg, P. M. (2009). The relation between public speaking anxiety and social anxiety: A review. Journal of Anxiety Disorders, 23(3), 305-313.

Cheng, Y. (2002). Factors associated with foreign language writing anxiety. Foreign Language Annals, 35(6), 647-656.

Connolly, S., Simpson, D., \& Petty, C. (2006). Anxiety Disorders. New York: Chelsea House Publishers.
Cowden, P. (2010). Communication and conflict: Anxiety and learning. In the Proceedings of Academy of Organizational Culture: Communications and Conflict, 14(2), 16-19.

Depdiknas. (2005). Pedoman pengembangan system asesmen berbasis kompetensi. Jakarta: Dirjen Ketenagaan Dikti.

Ehrenreich-May, J., \& Bilek, E. L. (2012). The development of a transdiagnostic, cognitive behavioral group intervention for childhood anxiety disorders and co-occurring depression symptoms. Cognitive and Behavioral Practice, 19(1), 41-55.

Freud, S. (2013). The problem of anxiety. Read Books Ltd.

Gkonou, C. (2011). Anxiety over NFL speaking and writing: A view from language classrooms. Studies in Second Language Learning and Teaching, 1(2), 267-281.

Handayani, I., \& Rahmawati, E. (2017). Students' Speaking Anxiety at English Classroom in Agroecotechnology Department of Agricultural Faculty Untirta (A Descriptive Study in AgroEcoTechnology Classroom, Untirta). Journal of English Language Studies, 2(2).

Huang, Q. (2012). Study on Correlation of Foreign Language Anxiety and English Reading Anxiety. Theory \& Practice in Language Studies, 2(7).

Kim, \& Kim. (2004). When the learner becomes a teacher: Foreign language anxiety as an occupational hazard. English Teaching, 59(1), 165-185.

Merç, A. (2011). Sources of Foreign Language Student Teacher Anxiety: A Qualitative Inquiry. Turkish Online Journal of Qualitative Inquiry, 2(4), 80-94. 
Miles, M., \& Huberman, A. (1994). An Expanded Sourcebook Qualitative Data Analysis. London: SAGE Publications.

Nguyen, \& Tran. (2015). Factors affecting students' speaking performance at Le Thanh Hien high school. Asian Journal of Education Research, 3(2), 8-23.

Noonan. (2007). How to improve your spoken English. Retrieved February 25, 2016, from About Education website: http://www.gdyzy.edu.cn/

Ohata, K. (2005). Potential Sources of Anxiety for Japanese Learners of English: Preliminary Case Interviews with Five Japanese College Students in the U. S . TESL-EJ, 9(3), 1-21.

PPL FKIP Unsyiah. (n.d.). Pedoman Program Pengalaman Lapangan FKIP Unsyiah.

Riasati. (2011). Language Learning Anxiety from EFL Learners' Perspective. Middle-East Journal of Scientific Research, 7(6), 907-914.

Saputra, J. B. (2018). An analysis of students'speaking anxiety toward their speaking skill. Premise: Journal of English Education, 7(1), 111-123.
Smith. (2009). Teaching Students in Inclusive Settings. Toronto: Pearson Publishing.

Tanveer, M. (2007). Investigation of the factors that cause language anxiety for $\mathrm{ESL} / \mathrm{EFL}$ learners in learning speaking skills and the influence it casts on communication in the target language. University of Glasgow, Scotland.

Timina, S. (2015). Causes of English speaking anxiety among Taiwanese university students. Proceedings of INTCESS15- 2nd International Conference on Education and Social Sciences, (February), 1305-1309.

Tseng, S. (2012). The factor cause language anxiety for ESL/EFL learners in learning speaking. An Interdisciplinary Journal, 63, 75-90.

Tum, D., \& Kunt, N. (2013). Speaking Anxiety Among Efl Student Teachers İngilizce Öğretmen Adaylarının Konuşma Kaygisı. H.U Journal of Education, 28(3), 385-399.

Woodrow, L. (2006). Anxiety and speaking English as a second language. RELC Journal, 37(3), 308-328. 